\title{
Porcine Pancreatic Prokallikrein. I. Its Partial Purification and Effects of Various Proteases on Its Activation
}

\author{
Kazuyuki Kizuki,* Masahiko Ikekita, Yuuji Shimamoto, and Hiroshi Moriya \\ Department of Biochemistry, Faculty of Pharmaceutical Sciences, Science University of \\ Tokyo, 12, Ichigaya Funakawara-machi, Shinjuku-ku, Tokyo 162, Japan
}

(Received February 12, 1982)

\begin{abstract}
Prokallikrein was partially purified from porcine pancreas by water extraction in the presence of soybean trypsin inhibitor, ethylenediaminetetraacetic acid (EDTA), $N$-ethylmaleimide and benzamidine, followed by a combination of ammonium sulfate fractionation, ion-exchange chromatographies, gel filtration and chromatofocusing in the presence of various protease inhibitors. The prokallikrein preparation obtained was stable on storage at $-25^{\circ} \mathrm{C}$; after 1.5 months only $2 \%$ of prokallikrein was activated. It was also fairly stable when it was lyophilized and stored at room temperature.

The prokallikrein was rapidly activated by trypsin. Chymotrypsin also activated prokallikrein, but an extremely large amount of chymotrypsin was necessary. Urokinase, cathepsins $\mathrm{C}$ and $\mathrm{D}$, plasmin, thrombin, Factor $\mathrm{Xa}$, collagenase, elastase, prolidase and leucine aminopeptidase caused no detectable activation of prokallikrein.

Several components of prokallikrein were detected by isoelectric focusing. The $\mathrm{p} I$ values of the two main components were 4.47 and 4.68 .

Slight spontaneous activation of prokallikrein occurred during the chromatographies even when the greatest care was taken.
\end{abstract}

Keywords_-kallikrein; porcine pancreatic kallikrein; prokallikrein; glandular kallikrein; kallikrein-kinin system; protease; activation; trypsin

Glandular kallikrein and plasma kallikrein are considered to have quite different physiological significance and/or pathological roles because their localization and enzymatic or other properties, i.e., behavior with kininogens, synthetic substrates, inhibitors, etc. are quite different from each other.

Various glandular kallikreins have been purified from various organs of many species and their properties investigated. However, the significance of the glandular kallikreins in the body and even the enzymes involved in the activation of glandular prokallikreins are still not well understood. One of the reasons for this is the difficulty of obtaining satisfactorily purified preparations of glandular prokallikrein due to many problems, such as rapid conversion to kallikrein during the purification procedures etc., although some groups have attempted to isolate glandular prokallikrein from pancreas, ${ }^{1,2)}$ urine $^{3)}$ and kidney) of mammals.

In the present work, we attempted to isolate porcine pancreatic prokallikrein with the eventual aim of elucidating the biological significance of glandular kallikrein in the body.

\section{Materials and Methods}

Materials_- Porcine pancreas (as fresh as possible) was obtained from a slaughterhouse and stored at $-25^{\circ} \mathrm{C}$ until required. Trypsin from porcine pancreas (Type I, $2 \mathrm{X}$ crystallized), tosyllysine chloromethy! ketone (TLCK)-treated $\alpha$-chymotrypsin from bovine pancreas $(49 \mathrm{U} / \mathrm{mg})$, cathepsins $\mathrm{C}(16 \mathrm{U} / \mathrm{mg})$ and $\mathrm{D}(12.5$ $\mathrm{U} / \mathrm{mg}$ ) from bovine spleen, prolidase from bovine kidney $(180 \mathrm{U} / \mathrm{mg}$ ), leucine aminopeptidase (Type III-CP, $100 \mathrm{U} / \mathrm{mg}$ ) and trypsin inhibitor from soybean (SBTI) (Type I-S) were from Sigma Chemical Co. (St. Louis, Mo., U.S.A.). SBTI (code No. 36-571) from Miles Laboratories Ltd. (Goodwood, South Africa) was also used only during water extraction of prokallikrein. Diethylaminoethyl (DEAE)-cellulose, carboxymethyl (CM)-cellulose and $N$-ethylmaleimide were obtained from Nakarai Chemicals Ltd. (Kyoto). Sephadex G-75, DEAE-Sephacel and the reagents for chromatofocusing (Polybuffer 74 and PBE 94) were purchased from Pharmacia Fine Chemicals (Uppsala, Sweden). Thrombin from human plasma (20 U/vial), Factor $\mathrm{X}_{\mathrm{a}}$ from 
bovine plasma ( $5 \mathrm{U} / \mathrm{vial}$ ) and collagenase $(15 \mathrm{U} / \mathrm{vial})$ were also obtained from Boehringer Mannheim $\mathrm{GmbH}$ (West Germany). Elastase which had been highly purified in our laboratory $\left(7.48 \mathrm{U} / E_{280}\right.$; substrate, succinyltrialanine-p-nitroanilide) was also used in this investigation. Antipain, chymostatin, leupeptin and pepstatin were generous gifts from Dr. T. Aoyagi of the Institute of Microbial Chemistry, Tokyo, and urokinase (high molecular weight, human urinaty, $3000 \mathrm{I}$.U./vial) and plasmin (human serum, $25 \mathrm{CU} /$ vial) were generous gifts from S. Morichi of the Green Cross Co., Osaka.

Esterolytic Activity Assay-Esterolytic activity towards $N^{\alpha}$-benzoyl-L-arginine ethyl ester (BzArgOEt) was photometrically measured as a kallikrein assay (final substrate concentration, $0.5 \mathrm{~mm}$ ), ${ }^{5 \text { ) }}$ and the activity was expressed in esterase units (EU). One EU is the amount of enzyme that can hydrolyze $1 \mu \mathrm{mol}$ of BzArgOEt per min at $25^{\circ} \mathrm{C}$ and $\mathrm{pH} 8.0$. Trypsin can activate porcine pancreatic prokallikrein, ${ }^{1 /}$ so that the amount of prokallikrein was determined in the following way, even though it is unclear whether or not trypsin is a natural activator of prokallikrein under normal physiological or pathological conditions. Prokallikrein solution, $0.2 \mathrm{ml}$, was incubated with $0.1 \mathrm{ml}$ of trypsin solution $(1 \mathrm{mg} / \mathrm{ml}$ in $0.01 \mathrm{~m}$ Tris- $\mathrm{HCl}$ buffer, $\mathrm{pH} 8.0)$ for a certain period at $25^{\circ} \mathrm{C}$ (activation of prokallikrein). Next, $0.1 \mathrm{ml}$ of SBTI solution $(3 \mathrm{mg} / \mathrm{ml}$, in the same buffer) was added to it, the esterolytic activity of this mixture was measured and the amount of prokallikrein was estimated and expressed as EU after activation.

Vasodilative Activity Assay in Dog _... The vasodilative activity was determined by measuring the increase in arterial blood flow following the injection of samples into the femoral artery of an anesthetized dog according to the method of Moriya et al. ${ }^{61}$

Isoelectric Focusing Fractionation-_- The sample solution was applied to an Ampholine column (column size, $110 \mathrm{ml}$ ) using the LKB apparatus.7) The $\mathrm{pH}$ range of carrier Ampholyte was $3.5-6$ and electrophoresis was carried out for $40 \mathrm{~h}$ at constant voltage $(600 \mathrm{~V})$ with a cooling system $\left(4^{\circ} \mathrm{C}\right)$. The $\mathrm{pH}$ 's of the fractions were measured and the amount of prokallikrein was determined as mentioned above.

\section{Results}

\section{Purification of Prokallikrein}

Table I shows a summary of the partial purification of prokallikrein from porcine pancreas. All of the procedures were carried out at $0-2{ }^{\circ} \mathrm{C}$. Hog pancreas $(522 \mathrm{~g})$ was minced with a meat grinder and $1200 \mathrm{ml}$ of distilled water containing SBTI, benzamidine, EDTA and $N$ ethylmaleimide was added. The final concentrations of SBTI, benzamidine, EDTA and $N$ ethylmaleimide were $5 \mathrm{mg} / \mathrm{g}$ pancreas, $1 \times 10^{-2} \mathrm{~m}, 1 \times 10^{-3} \mathrm{M}$ and $1 \times 10^{-3} \mathrm{M}$, respectively. The solution was adjusted to $\mathrm{pH} 5.0$, and stirred for $1 \mathrm{~h}$. Then, it was centrifuged for $30 \mathrm{~min}$ at $6000 \mathrm{rpm}$ and the supernatant was obtained. Solid ammonium sulfate was added to this solution and the precipitate formed between $40-70 \%$ saturation was collected. The precipitate was suspended in $\mathrm{H}_{2} \mathrm{O}$ containing antipain, chymostatin, leupeptin, pepstatin (final concentrations, each $2 \mu \mathrm{g} / \mathrm{ml}$ ) and $10 \mathrm{mg}$ of SBTI, and dialyzed for $8 \mathrm{~h}$ against $\mathrm{H}_{2} \mathrm{O}$. After centrifugation $(6000 \mathrm{rpm}, 30 \mathrm{~min})$, the $\mathrm{pH}$ and the electric conductivity of the supernatant were adjusted to 6.0 and $2.7 \mathrm{mmho}$, respectively, and the solution was applied to a CM-cellulose column $(4.5 \mathrm{~cm} \times 30 \mathrm{~cm})$ equilibrated with 2.7 mmho ammonium acetate buffer, $\mathrm{pH}$ 6.0. Non-adsorbed materials were then applied to a DEAE-cellulose column and the materials adsorbed on the column were eluted (Fig. 1). The esterase activity and the amount of protein (absorbance at $280 \mathrm{~nm}$ ) of the solutions obtained prior to the 1st DEAE-cellulose chromatography could not be measured because insoluble materials, such as fat, etc., were emulsified in these solutions. As shown in Fig. 1, prokallikrein (fractions No. 77-120) was eluted before the active kallikrein (fractions No. 110-170) and almost complete separation was achieved. Two prokallikrein peaks were observed on this chromatogram but these two peaks were not completely separated, so their mixture (fractions No. 77-107), which contained no active kallikrein, was further purified on a Sephadex G-75 column. Fig. 2 shows the elution profile of the prokallikrein on the Sephadex G-75 column. After this gel filtration, a small amount of active kallikrein was detected in the same fractions as prokallikrein. This active kallikrein is probably kallikrein spontaneously activated from the prokallikrein during or after the gel filtration, because we had pooled as the starting material for this process prokallikrein fractions which contained no active form, as shown in Fig. 1. Fractions No. 31 to 39 were pooled and the 2nd and 3rd DEAE-cellulose chromatographies were carried out (Figs. 3 an 4). The 
small active kallikrein peak located after the prokallikrein peak shown near fraction No. 40 in Fig. 3 is presumably derived from the active kallikrein shown in the previous chromatogram (Fig. 2), i.e., active kallikrein shown in Fig. 2 which could not be separated from prokallikrein by Sephadex G-75 gel filtration was separated by the subsequent ion-exchange chromatography. A small active kallikrein peak was also observed in Fig. 4. These small amounts of active kallikrein are presumably spontaneously generated from prokallikrein during these chromatographies. At present, the reason for these slight spontaneous activations of prokallikrein during these or following chromatographies is unclear, so we could not completely block this slight spontaneous activation. As adequate purification of prokallikrein could not be achieved

TABle I. Summary of the Partial Purification of Porcine Pancreatic Prokallikrein

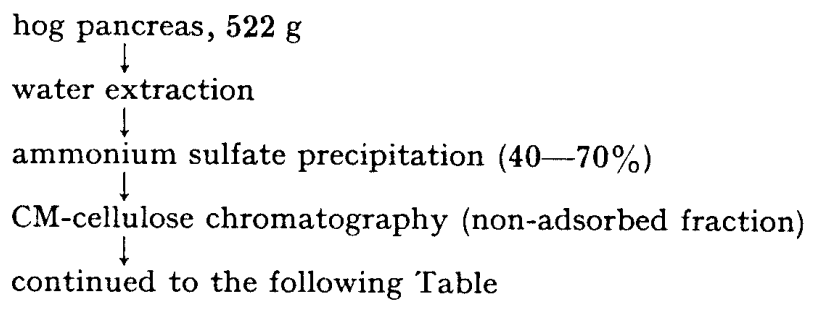

\begin{tabular}{|c|c|c|c|c|c|c|}
\hline Chromatographies ${ }^{a}$ & $\begin{array}{l}\text { Protein } \\
\left(E_{\mathbf{2 8 0}}\right)\end{array}$ & $\begin{array}{c}\text { Recovery } \\
(\%)\end{array}$ & $\begin{array}{l}\text { Prokallikrein } \\
\qquad(E U)^{b)}\end{array}$ & $\begin{array}{l}\text { Recovery } \\
(\%)\end{array}$ & $\begin{array}{l}\text { Specific activity } \\
\left(\mathrm{EU} / E_{\mathbf{2 8 0}}\right)\end{array}$ & P.F. \\
\hline 1st DEAE-cellulose & 852.3 & 100 & $296.7(0 \%)^{e)}$ & 100 & 0.35 & 1 \\
\hline Sephadex G-75 & 254.9 & 29.9 & $241.1(5.9 \%)$ & 81.3 & 0.95 & 2.7 \\
\hline 2nd DEAE-cellulose & 79.1 & 9.3 & $129.5(2.5 \%)$ & 43.6 & 1.64 & 4.7 \\
\hline 3rd DEAE-cellulose & 50.0 & 5.9 & $122.2(2.7 \%)$ & 41.2 & 2.4 & 7 \\
\hline Chromatofocusing & 14.5 & 1.7 & $89.6(4.8 \%)$ & 30.2 & 6.2 & 18 \\
\hline DEAE-Sephacel & 5.7 & 0.67 & $52.1(0 \%)$ & 17.6 & 9.1 & 26 \\
\hline Sephadex G-75 & 3.3 & 0.39 & $41.5(8.5 \%)$ & 14.0 & 12.6 & 36 \\
\hline
\end{tabular}

a) Antipain, chymostatin, leupeptin and pepstatin were added to the elution buffer used (final concentrations, each $2 \mu \mathrm{g} / \mathrm{ml}$ )

b) Assayed after treatment with trypsin.

c) Contents of the active form of kallikrein (EU, untreated/EU, treated with trypsin $\times 100$ ).

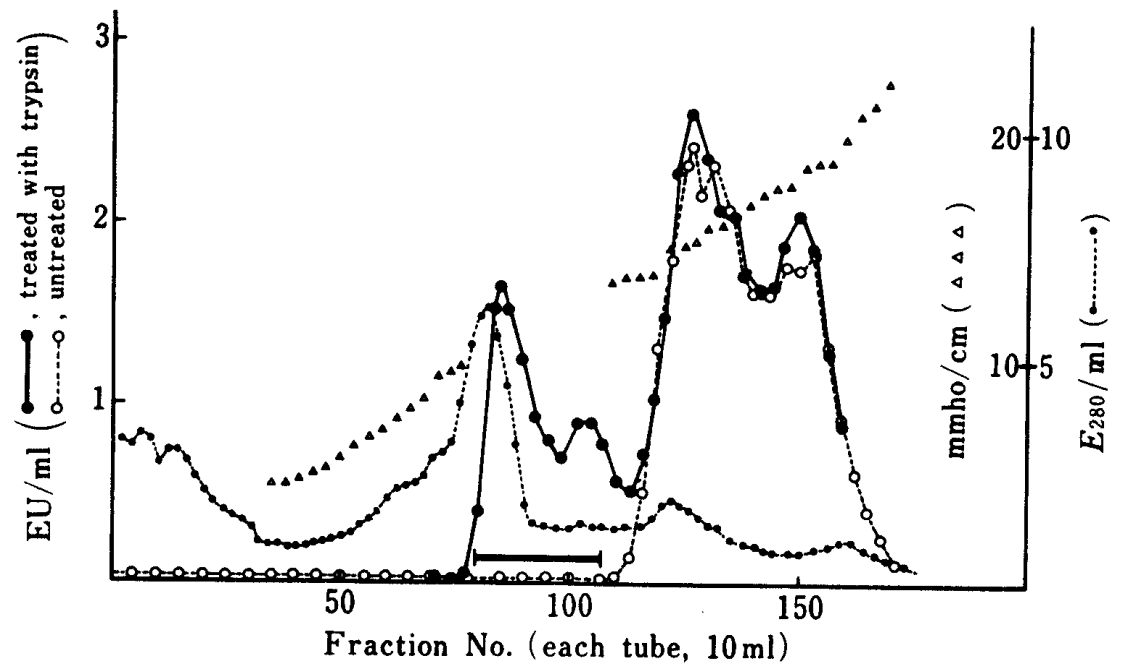

Fig. 1. First DEAE-Cellulose Chromatography of the Non-adsorbed Fractions from a CM-Cellulose Column

Fractions not adsorbed on a CM-cellulose column were directly applied to a DEAEcellulose column $(3.5 \mathrm{~cm} \times 34 \mathrm{~cm})$ equilibrated with 2.7 mmho ammonium acetate, $\mathrm{pH}$ 6.0. Then, linear gradient elution with ammonium acetate, $\mathrm{pH} 6.0$ (4.5 to 40 mmho, total $2000 \mathrm{ml}$ ) was carried out. $\longmapsto$ in the figure shows the pooled fractions; the same symbol is used in the following figures (Figs. 2-7). 
by 2nd and 3rd DEAE-cellulose chromatographies, the prokallikrein fractions of 3rd DEAEcellulose chromatography were further purified by chromatofocusing fractionation. As shown in Fig. 5, prokallikrein was adsorbed on the gel bed (PBE 94) but could hardly be eluted by a gradient of Polybuffer 74 because the $\mathrm{pH}$ could not be sufficiently lowered by the procedure mentioned in the instruction manual for chromatofocusing. Therefore, excess amounts of Polybuffer 74 were further added to reduce the $\mathrm{pH}$ of the eluate sufficiently. Prokallikrein was eluted at $\mathrm{pH}$ 4.3. However, the $\mathrm{pH}$ of the eluate could not be decreased below 4.1 (probably due to the characteristic properties of PBE 94) and the prokallikrein was eluted as a broad peak. Thus, prokallikrein was eluted sharply with $1 \mathrm{~m} \mathrm{NaCl}$. Fractions No. 115 to 132 were pooled and further purified on a DEAE-Sephacel column (Fig. 6). In this case, active kallikrein corresponding to the active kallikrein shown in Fig. 5 was not eluted from the column, and may have remained in the column. Fractions that contained prokallikrein were pooled and further gel-filtered on a Sephadex G-75 column (Fig. 7). Pooled prokallikrein fractions in Fig. 7 had a specific activity of $12.6 \mathrm{EU} / E_{280}$ (when assayed after activation with trypsin) and contained $8.5 \%$ activated form. This prokallikrein preparation had several protein contaminants when analyzed by disc gel electrophoresis on polyacrylamide $(10 \%, \mathrm{w} / \mathrm{v})$. This preparation was mainly used in the following investigations.

\section{Stability of Porcine Pancreatic Prokallikrein}

Table II shows the stability of porcine pancreatic prokallikrein when it was stored

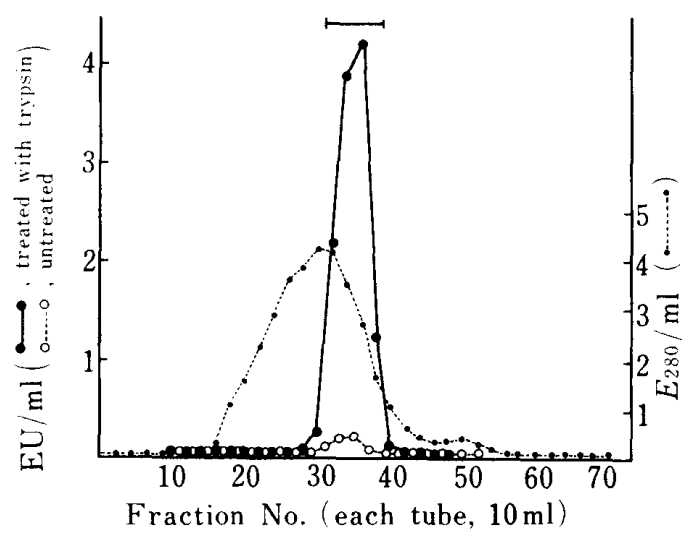

Fig. 2. Sephadex G-75 Gel Filtration of Prokallikrein obtained from the 1st DEAE-Cellulose Chromatography

Fractions containing prokallikrein in Fig. 1 were pooled, concentrated to $15 \mathrm{ml}$ and applied to a Sephadex G-75 column $(2.6 \mathrm{~cm} \times 92 \mathrm{~cm})$ equilibrated with 2.7 mmho ammonium acetate, $\mathrm{pH} 6.0$.

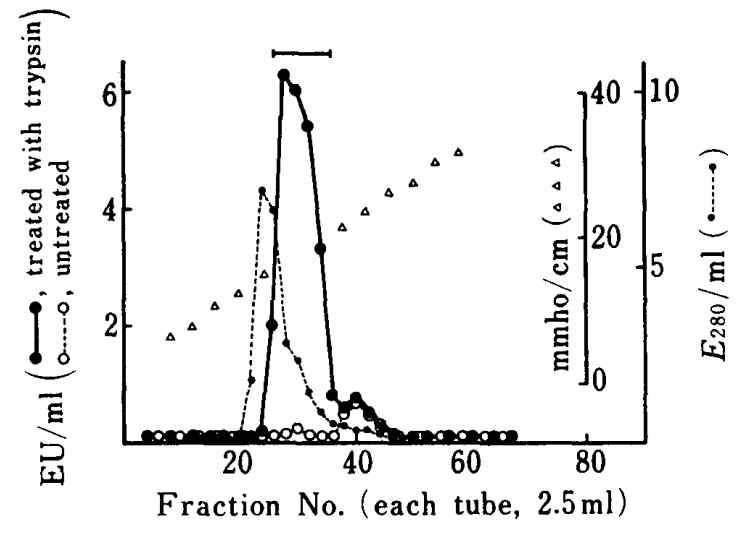

Fig. 3. Second DEAE-Cellulose Chromatography of the Prokallikrein Fractions obtained from Sephadex G-75 Gel Filtration

Prokallikrein fractions obtained by Sephadex G-75 gel filtration were directly applied to a DEAE-cellulose column $(1.3 \mathrm{~cm} \times 15 \mathrm{~cm})$ equilibrated with 4 mmho ammonium acetate, $\mathrm{pH} 6.0$, then adsorbed materials were eluted with a linear gradient of ammonium acetate, pH 6.0 (4 to $43 \mathrm{mmho}$, total $220 \mathrm{ml}$ ).

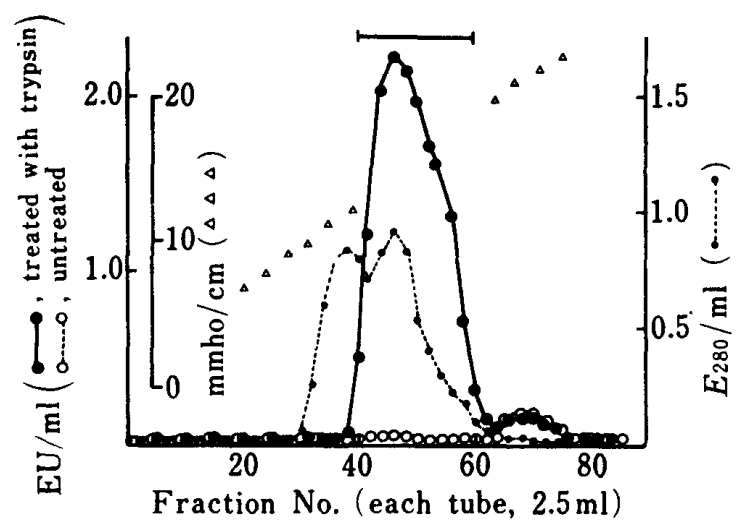

Fig. 4. Third DEAE-Cellulose Chromatography of Prokallikrein Fractions obtained from the 2nd DEAE-Cellulose Chromatography

Prokallikrein fractions in Fig. 3 were pooled and the electric conductivity and $\mathrm{pH}$ of the solution were adjusted to $3 \mathrm{mmho}$ and 6.0 , respectively, with $\mathrm{H}_{3} \mathrm{O}$. Then, the solution was applied to a DEAE-cellulose column $(1.3 \mathrm{~cm} \times 15 \mathrm{~cm})$ equilibrated with 2.7 mmho ammonium acetate, $\mathrm{pH}$ 6.0. Linear gradient elution with ammonium acetate, pH $6.0(2.7$ to 23 mmho, total $220 \mathrm{ml}$ ) was carried out. 


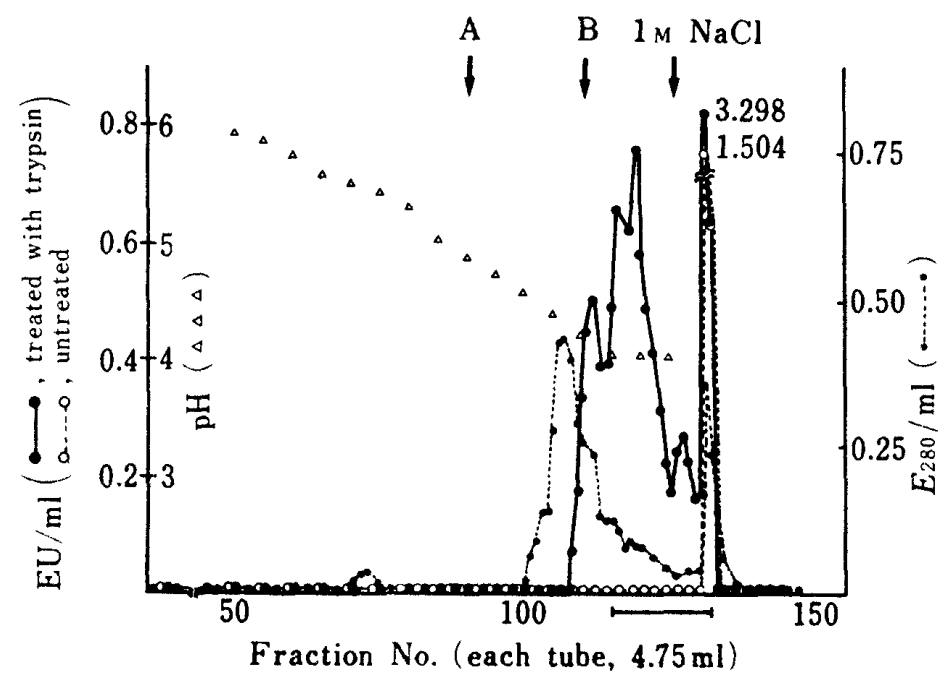

Fig. 5. Elution Profile of Prokallikrein from a PBE 94 Column

Prokallikrein fractions obtained from the 3rd DEAE-cellulose chromatography were pooled and concentrated to about $20 \mathrm{ml}$ with polyethylene glycol, then dialyzed against $0.025 \mathrm{M}$ histidine- $\mathrm{HCl}$ buffer, $\mathrm{pH}$ 6.2 , which was also used for equilibration of the PBE 94 column $(1.4$ $\mathrm{cm} \times 30 \mathrm{~cm})$. Then, the solution was applied to the column and eluted with a linear gradient formed from the same buffer $(250 \mathrm{ml})$ and Polybuffer $74(250 \mathrm{ml})$ which had been diluted 8 times with $\mathrm{H}, \mathrm{O}$ and adjusted to $\mathrm{pH} 3.9$ with $\mathrm{HCl}$. However, prokallikrein was not eluted, so 4-times-diluted Polybuffer $74, \mathrm{pH} 3.9(100 \mathrm{ml})(\mathrm{A}$ in Fig. 5) and undiluted Polybuffer 74, pH $3.4(100 \mathrm{ml})$ (B in Fig. 5) were further added.

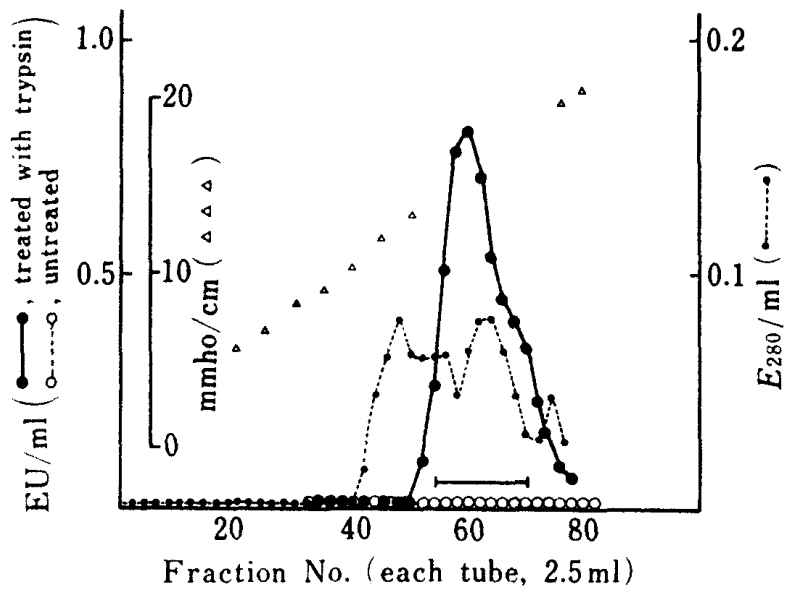

Fig. 6. Elution Profile of Prokallikrein from a DEAE-Sephacel Column

Prokallikrein fractions in Fig. 5 were pooled and dialyzed against $2.5 \mathrm{mmho}$ ammonium acetate, $\mathrm{pH} \mathrm{6.8}$. Then, the solution was applied to a DEAE-Sephacel column $(1.3 \mathrm{~cm} \times$ $15 \mathrm{~cm}$ ) equilibrated with the same buffer. Linear gradient elution with 2.2 to 22 mmho ammonium acetate, $\mathrm{pH} 6.8$ (total $240 \mathrm{ml}$ ) was carried out .

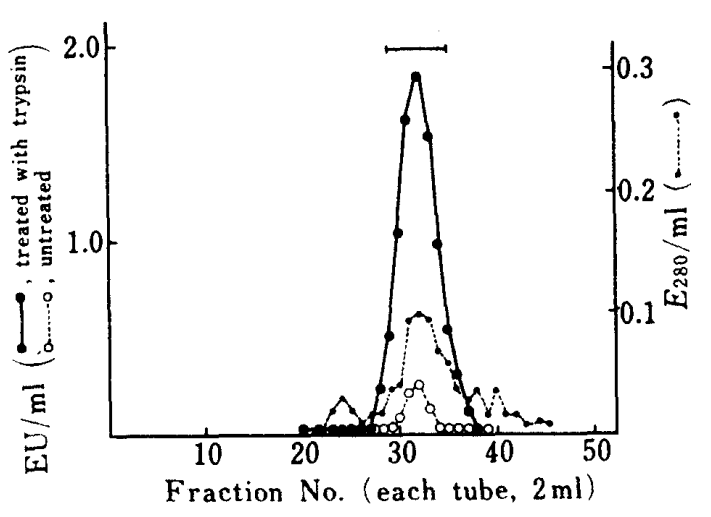

Fig. 7. Sephadex G-75 Gel Filtration of Prokallikrein obtained from the DEAESephacel Chromatography

Prokallikrein fractions in Fig. 6 were pooled, concentrated to $5 \mathrm{ml}$ and applied to a Sephadex G-75 column $(1.5 \mathrm{~cm} \times 85 \mathrm{~cm})$ equilibrated with 5 mmho ammonium acetate, $\mathrm{pH} 6.0$.

at $-25^{\circ} \mathrm{C}$, or at room temperature after lyophilization. The prokallikrein solution (control, A in Table II), which was the preparation obtained by the last Sephadex G-75 gel filtration, originally contained $8.5 \%$ active form. As shown in B in Table II, this prokallikrein preparation was stable as the pro- form when it was frozen and stored at $-25^{\circ} \mathrm{C}$; after 1.5 months a slightly increased content of active kallikrein (10.4\%) was observed, so that only $1.9 \%$ of prokallikrein was spontaneously activated during this storage period. It was also fairly 
TABle II. Stability of the partially purified Porcine Pancreatic Prokallikrein when It was frozen and stored at $-25^{\circ} \mathrm{C}$, or lyophilized and stored at Room Temperature

\begin{tabular}{|c|c|c|c|c|}
\hline & \multicolumn{2}{|c|}{ Activity $(\mathrm{EU} / \mathrm{ml})$} & \multirow{2}{*}{$\begin{array}{l}\text { Contents of } \\
\text { active } \\
\text { kallikrein }^{a l}\end{array}$} & \multirow{2}{*}{$\begin{array}{l}\text { Active kallikrein } \\
\text { generated during } \\
\text { the storage period }\end{array}$} \\
\hline & Trypsin-treated & Active form & & \\
\hline $\begin{array}{l}\text { (A) Control (last Sephadex } \\
\text { G-75 eluate) }\end{array}$ & 0.846 & 0.072 & $8.5 \%$ & - \\
\hline (B) Stored at $-25^{\circ} \mathrm{C}$ (1.5 months) & 1.708 & 0.178 & $10.4 \%$ & $1.9 \%$ \\
\hline $\begin{array}{c}\text { (C) Lyophilized and stored at room } \\
\text { temperature ( } 2 \text { months) }\end{array}$ & 0.274 & 0.066 & $24.1 \%$ & $15.6 \%$ \\
\hline
\end{tabular}

a) (active form/trypsin-treated) $\times 100$.

(B): a part of (A) was concentrated with polyethylene glycol and stored at $-25^{\circ} \mathrm{C}$ after dialysis against $\mathrm{H}_{2} \mathrm{O}$.

(C): a part of (A) was dialyzed against $\mathrm{H}_{2} \mathrm{O}$ at $0^{\circ} \mathrm{C}$, then lyophilized and stored in a desiccator at room temperature.

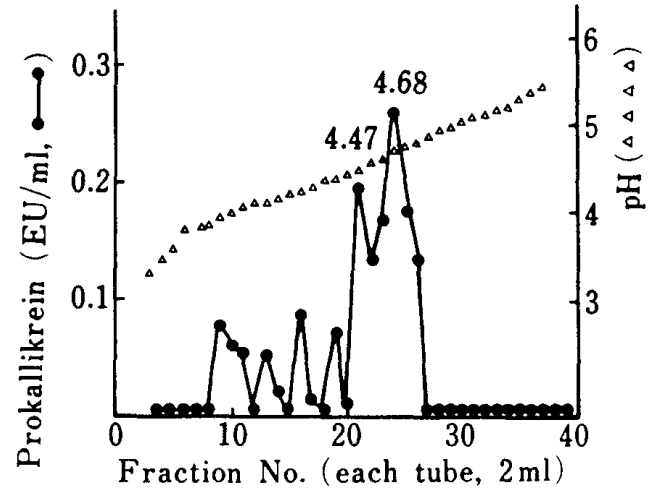

Fig. 8. Isoelectric Focusing Chromatography of the Prokallikrein Fractions obtained from the 1st DEAE-Cellulose Chromatography

The amount of prokallikrein is expressed as EU (treated with trypsin) minus EU (untreated).

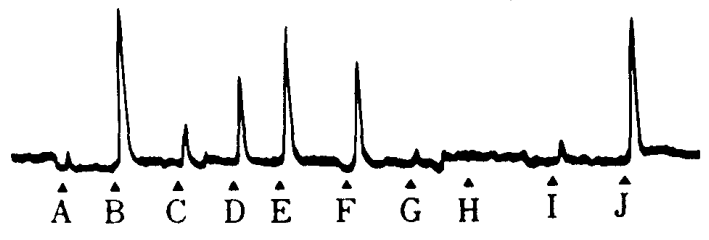

Fig. 9. Vasodilative Activity of the partially Purified Porcine Pancreatic Prokallikrein in a Dog
(A): prokallikrein, $\times 400,0.2 \mathrm{ml}$.
(B): trypsin-treated prokallikrein, $\times 400,0.2 \mathrm{ml}$.
(C), (D) and (E): $0.00125,0.0025$ and $0.005 \mathrm{KU}$ of the standard porcine pancreatic kallikrein.
(F): trypsin-treated prokallikrein, $\times 400,0.1 \mathrm{ml}$
(G): trypsin plus SBTI, $\times 400,0.1 \mathrm{ml}$.
(H): prokallikrein, $\times 400,0.1 \mathrm{ml}$.
(I): prokallikrein, $\times 20,0.1 \mathrm{ml}$.
(J): prokallikrein, $\times 1,0.05 \mathrm{ml}$.
$\times 400, \times 200, \times 20$ and $\times 1$ : Dilution factors.

stable when a sample was lyophilized and stored in a desiccator at room temperature; after 2 months, $15.6 \%$ was activated (C in Table II).

\section{Isoelectric Focusing Fractionation}

Fig. 8 shows the results of isoelectric focusing chromatography of the fractions containing prokallikrein derived from the first DEAE-cellulose chromatography. As shown in Fig. 8, several components of prokallikrein were detected. The $\mathrm{p} I$ values of the main two components were 4.47 and 4.68 .

\section{Vasodilative Activity Assay}

One of the typical biological activities of kallikrein is its potent vasodilative activity. Thus, the vasodilative activity of the preparation of prokallikrein (pro- form fractions after DEAE-Sephacel chromatography) was determined by measuring the increase in arterial blood flow in a dog (Fig. 9). As shown in A in Fig. 9, untreated prokallikrein caused no change in arterial blood flow, whereas prokallikrein treated with trypsin caused a marked increase of arterial blood flow (B and F). The mixture of trypsin and SBTI had no effect on arterial blood flow $(G)$. Thus, the marked increase of arterial blood flow caused by the trypsin-treated prokallikrein preparation ( $B$ and $F$ ) must be explained as the result of activation of prokallikrein by trypsin. Therefore, it is concluded that our preparation is the zymogen of porcine pancreatic kallikrein. On the other hand, injection of a large amount of untreated prokallikrein also 
caused some increase of arterial blood flow, probably due to the contamination of a small amount of active kallikrein ( $\mathrm{H}$ to $\mathrm{J}$ ). The vasodilative activities of this preparation before $(\mathrm{J})$ and after $(\mathrm{B}$ and $\mathrm{F})$ treatment with trypsin were calculated to be 0.1 and $13.6 \mathrm{KU} / \mathrm{ml}$ (KU; kallikrein unit), respectively. Thus, the content of active form in this preparation measured by the vasodilator assay was $0.74 \%$, although that measured by the esterolytic assay was none (see Table I). The reason for this difference might be the different sensitivities of these two assay methods; the sensitivity of vasodilator assay for kallikrein is extremely high.

\section{Effects of Various Proteases on Activation of Prokallikrein}

The ability of various proteases to activate porcine pancreatic prokallikrein was investigated by using prokallikrein preparation obtained from the last Sephadex G-75 gel filtration. Fig. 10 shows the time courses of activation of prokallikrein by trypsin at $0^{\circ} \mathrm{C}$. Trypsin rapidly activated prokallikrein at normal temperature, so that incubation of prokallikrein with trypsin was carried out at $0^{\circ} \mathrm{C}$. As shown in Fig. 10, $0.05 \mathrm{EU} / \mathrm{ml}$ (final concentration) of trypsin gradually activated porcine pancreatic prokallikrein with the lapse of incubation time. On the other hand, maximum activation was observed within $5 \mathrm{~min}$ by $0.35 \mathrm{EU} / \mathrm{ml}$ of trypsin. No detectable activation was observed in untreated prokallikrein preparation even upon incubation at $25^{\circ} \mathrm{C}$ (control). These findings show that porcine pancreatic prokallikrein was indeed enzymatically activated by the action of trypsin.

Fig. 11 shows the activating effects of various proteases other than trypsin on prokallikrein. As shown in Fig. 11, urokinase, cathepsins C and D, plasmin, thrombin, Factor Xa, collagenase, elastase, prolidase and leucine aminopeptidase (A in Fig. 11) caused no detectable activation of porcine pancreatic prokallikrein at $0^{\circ} \mathrm{C}$ or even at $25^{\circ} \mathrm{C}$ with high doses. TLCK-treated chymotrypsin partially activated prokallikrein but an extremely large amount of chymotrypsin (final concen-tration, $1 \mathrm{mg} / \mathrm{ml}$ ) was necessary as compared with trypsin.

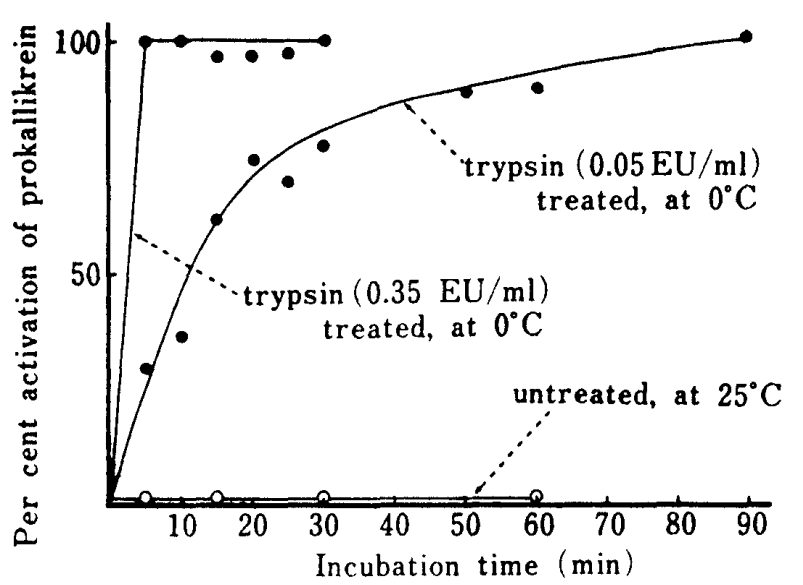

Fig. 10. Activation of Porcine Pancreatic Prokallikrein by Trypsin

One $\mathrm{ml}$ of prokallikrein solution was incubated with $1 \mathrm{ml}$ of trypsin solution at $0^{\circ} \mathrm{C}$. After the indicated periods, 0.2 $\mathrm{ml}$ of this mixture was taken into a test tube and $0.1 \mathrm{ml}$ of SBTI solution $(3 \mathrm{mg} / \mathrm{ml})$ was added to it. Then, the esterase activity of this mixture was assayed. The amount of prokallikrein activated was expressed as per cent of the amount of prokallikrein initially present.

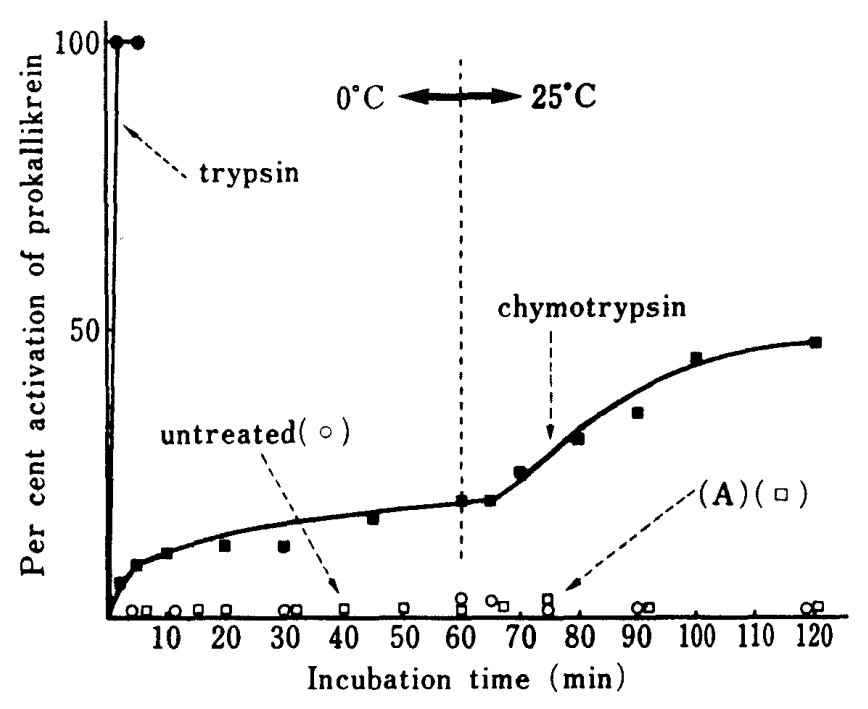

Fig. 11. Effects of Various Proteases on Activation of Porcine Pancreatic Prokallikrein

One $\mathrm{ml}$ of prokallikrein solution was incubated with $1 \mathrm{ml}$ of various protease solutions as shown in the figure at 0 and $25^{\circ} \mathrm{C}$. After the indicated periods, the esterase activities of the mixtures $(0.1 \mathrm{ml})$ were assayed. Except in the case of trypsin, if the protease itself had esterase activity against BzArgOEt, its activity was subtracted from the value obtained.

Final enzyme concentrations; trypsin, $0.5 \mathrm{mg} / \mathrm{ml}$; $\alpha$-chymotrypsin (TLCK-treated), $1 \mathrm{mg} / \mathrm{ml}$; cathepsin C, $0.25 \mathrm{mg} / \mathrm{ml}$; cathepsin D, $0.1 \mathrm{mg} / \mathrm{ml}$; urokinase, $750 \mathrm{I}$.U. $/ \mathrm{ml}$; prolidase $0.5 \mathrm{mg} / \mathrm{ml}$; elastase, $2.5 \mathrm{mg} / \mathrm{ml}$; plasmin, $3 \mathrm{CU} / \mathrm{ml}$; leucine aminopeptidase, $0.5 \mathrm{mg} / \mathrm{ml}$; factor $\mathrm{X}_{\mathrm{a}}, 1.25 \mathrm{U} / \mathrm{ml}$; collagenase, $3.7 \mathrm{U} / \mathrm{ml}$; thrombin, $2.5 \mathrm{U} / \mathrm{ml}$. 


\section{Discussion}

Kallikrein in the pancreas exists as an inactive form, prokallikrein, and its activation in normal physiological and/or various pathological states may be regulated by other proteases present in the pancreas or body fluids. An excellent way to elucidate the biological significance of glandular kallikrein in the body would be to identify enzyme(s) involved in the activation of prokallikrein in the body and to clarify the mechanism of activation of prokallikrein. For this purpose, isolation of prokallikrein is necessary. However, isolation of prokallikrein from the pancreas is very difficult because considerable amounts of prokallikrein are rapidly activated to kallikrein by proteases present in the pancreas during its extraction into water. Some groups have attempted to isolate prokallikrein from the pancreas ${ }^{1,2)}$ urine $^{3)}$ and kidney ${ }^{4)}$ of mammals but a satisfactorily purified preparation has not been obtained in many cases. One reason for this must be rapid activation as mentioned above, and another must be that prokallikrein is gradually or rapidly activated to kallikrein during the purification processes as shown in Fiedler's report. ${ }^{1)}$ Thus, it has not previously been possible to obtain a stable preparation (as intact prokallikrein) even in partially purified form.

The authors extracted prokallikrein from porcine pancreas in the presence of various protease inhibitors, i.e., SBTI, EDTA, $N$-ethylmaleimide and benzamidine, at $0^{\circ} \mathrm{C}$ in order to block the activation of prokallikrein by proteases present in the pancreas, and after DEAEcellulose chromatography about $30 \%$ of kallikrein was obtained as an inactive pro- form (Fig. 1). For the first water extraction, addition of SBTI (mainly the purpose to inhibit trypsin) was absolutely necessary. In our experience, the minimum concentration of SBTI required was $3 \mathrm{mg} / \mathrm{g}$ pancreas. If the concentration was lower than this value, e.g. $1 \mathrm{mg} / \mathrm{g}$ pancreas, the yield of prokallikrein decreased markedly. Little increase of yield of prokallikrein was observed upon further addition of EDTA, $N$-ethylmaleimide and benzamidine in addition to SBTI, but all of these inhibitors were used for the first step of water extraction because at present we have no knowledge of what enzyme(s) in addition to trypsin may be involved in the activation of prokallikrein.

In the purification steps after the first DEAE-cellulose chromatography, buffers containing various microbial protease inhibitors were used. Addition of these inhibitors was seemed to suppress (though not completely) the spontaneous activation of prokallikrein during the chromatographies. In experiments in which these inhibitors were not added, marked spontaneous activation of prokallikrein was frequently observed. At present, the cause of the spontaneous activation of prokallikrein during the chromatographies with or without these inhibitors is not known.

As mentioned in "Results," two prokallikrein components were observed in the 1st DEAEcellulose chromatography. However, we could not observe two distinct prokallikrein peaks corresponding to these two components in the ion-exchange chromatographies subsequent to the 1st DEAE-cellulose chromatography. This may be because we pooled only the fractions that contained no active kallikrein in Fig. 1, so that the content of one of the prokallikrein components eluted at high electric conductivity (fractions No. 100-107 in Fig. 1) in this pooled preparation was fairly low. Our final preparation probably still contains some of this component, however, because a slight shoulder was observed near fraction No. 70 in Fig. 6 .

Our final prepatation contained $8.5 \%$ active kallikrein but was stable as the pro- form during incubation at $25^{\circ} \mathrm{C}$ for $1 \mathrm{~h}$ (Fig. 10). Thus, this preparation was considered not to contain any enzyme that activates prokallikrein. The preparation was also stable on prolonged storage at $-25^{\circ} \mathrm{C}$ or on lyophilization followed by storage at room temperature (Table II). Thus, we obtained a stable prokallikrein preparation, though complete purification was not achieved. On the basis of the present experiments, however, it should be possible to achieve complete isolation of prokallikrein in the near future. 
Our final prokallikrein preparation was rapidly activated by a trace amount of trypsin (Fig. 10). TLCK-treated chymotrypsin also activated prokallikrein, but an extremely large amount of chymotrypsin $(1 \mathrm{mg} / \mathrm{ml})$ was necessary as compared with the amount of trypsin. No other enzymes investigated in the present work activated the prokallikrein. Judging from the results obtained here, trypsin is the only factor which could significantly activate prokallikrein at a physiological concentration. However, further detailed studies on other possible activating enzyme(s) should be performed in order to elucidate whether or not trypsin is the major activator of prokallikrein in normal physiological and/or pathological states in the body.

It has been shown that porcine pancreatic kallikrein obtained from autolyzed pancreas can usually be separated into two components, i.e., kallikreins $\mathrm{A}$ and $\mathrm{B}$, by anion-exchange chromatographies. ${ }^{8)}$ Kallikreins $\mathrm{A}$ and $\mathrm{B}$ can be further separated into several micro-heterogenous forms having different isoelectric points by the Ampholine isoelectric focusing technique. ${ }^{9)} \quad$ The $\mathrm{p} I$ value of the main micro-heterogenous component derived from kallikrein $\mathrm{A}$ (A-III) is 4.28 and the pI's of the two main micro-heterogenous components derived from kallikrein $\mathrm{B}$ (B-IV and $-\mathrm{V}$ ) are 4.30 and $4.50 .{ }^{9}$ ) In the present investigation, two prokallikrein components almost completely separated from active kallikrein (kallikreins A and B) were observed on the first DEAE-cellulose chromatography (these probably correspond to Fiedler's prokallikreins $A$ and $B$, but their prokallikrein $A$ was not distinctly separated from active kallikrein $\left.{ }^{1}\right)$. Furthermore, after isoelectric focusing chromatography of the fractions containing prokallikrein derived from the first DEAE-cellulose chromatography, several components of prokallikrein were detected. The $\mathrm{p} I$ values of the two main components were 4.47 and 4.68 . Judging from these observations, (micro-)heterogenous components of prokallikrein seem to be naturally present and the prokallikrein molecule seems to be more basic than active kallikrein derived from the corresponding prokallikrein. The detailed relationships among these (micro-)heterogenous components of prokallikrein and heterogenous or micro-heterogenous components of kallikreins obtained from autolyzed pancreas require further study.

Acknowledgements We would like to thank Dr. T. Aoyagi, Institute of Microbial Chemistry, Tokyo, and S. Morichi of the Green Cross Co., Osaka, for their generous gifts of various microbial enzyme inhibitors, and of urokinase and plasmin, respectively. This work was supported in part by a grant from the Ministry of Education, Science and Culture of Japan.

\section{References}

1) a) F. Fiedler, C. Hirschauer, and E. Werle, Hoppe-Seyler's Z. Physiol. Chem., 351, $225(1970)$; b) F. Fiedler and W. Gebhard, ibid., 361, 1661 (1980).

2) a) D. Proud, G.S. Bailey, T.B. Ørstavik, and K. Nustad, Biochem. Soc. Trans., 5, $1402(1977)$; b) R. Matsas, D. Proud, K. Nustad, and G.S. Bailey, Anal. Biochem., 113, 264 (1981).

3) a) J. Corthorn, T. Imanari, H. Yoshida, T. Kaizu, J. Pierce, and J. Pisano, Fed. Proc., 36, 893 (1977); b) J. Corthorn, T. Imanari, H. Yoshida, T. Kaizu, J.V. Pierce, and J.J. Pisano, "Advances in Experimental Medicine and Biology; KININS-II," Vol. 120B, ed. by S. Fujii, H. Moriya, and T. Suzuki, Plenum Press, New York, 1979, pp. 575-579.

4) K. Yamada and E.G. Erdös, Abstracts of Papers, International conference on Kallikreins, Kinins, Kininogens, Kininases, Munich, November, 1981, B.7.

5) G.W. Schwert and Y. Takenaka, Biochim. Biophys. Acta, 16, 570 (1955).

6) a) H. Moriya, K. Yamazaki, and H. Fukushima, J. Biochem. (Tokyo), 58, 201 (1965); b) C. Moriwaki, Y. Hojima, and H. Moriya, Chem. Pharm. Bull., 22, 975 (1974).

7) O. Verterberg and H. Svenssorn, Acta Chem. Scand., 20, 820 (1966).

8) a) C. Kutzbach and G. Schmidt-Kastner, Hoppe-Seyler's Z. Physiol. Chem., 353, 1099 (1972); b) M. Zuber and E. Sache, Biochemistry, 13, 3098 (1974).

9) a) M. Ikekita, H. Moriya, S. Ozawa, and K. Kizuki, Chem. Pharm. Bull., 29, 545 (1981); b) H. Moriya, Y. Fukuoka, Y. Hojima, and C. Moriwaki, Chem. Pharm. Bull., 26, $3178(1978)$; c) H. Moriya, M. Ikekita, and K. Kizuki, Chem. Pharm. Bull., 29, 1785 (1981); d) M. Ikekita, H. Moriya, K. Kizuki, and S. Ozawa, Chem. Pharm. Bull., 28, 1948 (1980). 